DOI: $10.17805 /$ trudy.2016.4.3

\title{
А. В. СУВОРОВ: РОЖДЕНИЕ ТАКТИКИ
}

\author{
А. П. Богданов \\ (Институт российской истории Российской Академии наук)
}

Аннотация: В статье рассмотрены первые шаги А. В. Суворова в формировании его нового военного искусства во время Семилетней войны. Понимая слабую документированность этого периода его военной биографии, полководец сам подробно рассказал о нем в автобиографии, выделив наиболее важные для развития его военной мысли моменты. Привлекая дополнительные источники, автор делает мысль Суворова понятной для современных историков.

Подготовлено на основе доклада автора на Всероссийской научной конференции «Военная история России», которая прошла в Московском гуманитарном университете 25 апреля 2016 г.

Ключевые слова: А. В. Суворов; военная тактика; военное искусство XVIII века; Семилетняя война; военный устав; история России

\section{A. V. SUVOROV: THE BIRTH OF TACTICS}

\section{A. P. Bogdanov \\ (Institute of Russian history, Russian Academy of Sciences)}

\begin{abstract}
The article examines Alexander Suvorov's first steps towards his new military tactics during the Seven Years' War. Since few documents on that early stage of his career had survived, Suvorov covered it in detail in his autobiography, emphasizing the events and facts of the war which proved to be the most important for his military thought. Bringing in information from some additional sources, the article attempts to make Suvorov's thought comprehensible for con-temporary historians.

This article is based on the paper presented at "The military history of Russia" conference, which was held at Moscow University for the Humanities on April 25, 2016

Keywords: A.V. Suvorov; military tactics; 18th century warfare; Seven Years' War; army regulations; history of Russia
\end{abstract}


«Жизнь столь открытая и известная, как моя, - написал А. В. Суворов в 1794 г. - никогда и никаким биографом искажена быть не может. Всегда найдутся неложные свидетели истины» (Суворов, 1987: 290).

К документированию своей биографии для современников и потомков он относился с такой же серьезностью и неослабным вниманием, как ко всем служебным делам. Исследование реального развития военной мысли Суворова показало (Богданов, 2014), что великий полководец особо выделял в своем становлении как полководца Прусскую кампанию 1761 г. Именно тогда, в конкретных обстоятельствах, рождалась его «смелая нападательная тактика», которой он в 1764-1769 гг. упорно обучал солдат в Ладоге и под Смоленском (Суворов, 1949: 66). Но этот важнейший для становления полководца период был, как понимал Александр Васильевич, слабо документирован. И Суворов, в своей автобиографии, на вершине побед, подробно и четко рассказал, как формировалась его военная мысль в ходе первой для него Прусской войны, от которой не сохранилось, как он знал, донесений и рапортов будущего непобедимого полководца. Между тем, именно тогда в его служебной жизни и мыслях произошел радикальный поворот, который сам полководец оценил высоко, и теперь должны понять мы.

Годы, проведенные им в нижних чинах, Суворов впоследствии описал словами: «Научись повиноваться, прежде чем будешь повелевать другими». Но как военная школа гвардия, которая не воевала с петровских времен, дала ему мало. «Я сам, с той поры как в армии, долго нес честную службу (в гвардии), но все равно три года ничего не стоил», - написал Суворов в 1787 г. Г. А. Потемкину (Суворов, 1987: 181). Выход из гвардии в чине поручика с назначением в Ингерманландский пехотный полкбыл обычным для гвардейцев преддверием отставки. Суворов был выпущен поручиком в полевую армию 25 апреля 1754 г., 10 мая получил назначение в полк, а уже 14 мая взял в Военной коллегии, где служил отец, отпуск домой на один год (Автократова, 1956: 213). За этим чаще всего следовали увольнение дворянина со службы и мирная жизнь в помещичьей усадьбе или городском доме. Для Суворова это было закономерным крушением мечты. Он получал повышения быстрее многих сверстников, по 10 и 15 лет остававшихся гвардии рядовыми, но, в общем-то, огромными стараниями к 26 годам ничего значительного не вы-служил.Так что после годового отпуска Александр в назначенный ему полк не вернулся. С начала 1756 г. он служил в Новгороде в качестве обер-провиантмейстера, усвоив тонкости и значение правильной организации снабжения армии.

Тщательная ревизия провиантских и фуражных магазинов позволила ему осенью занять пост генерал-аудитор лейтенанта Военной коллегии (Апушкин, 1899). Это была должность первого помощника генерал- 
аудитора, представлявшего военно-судебную власть над армейскими чинами до полковника. Как генерал-аудитор-лейтенант, Суворов с несколькими подчинявшимися ему обер-аудиторами рассматривал дела и утверждал приговоры военных судов, вплоть до разжалования в солдаты. Нестроевая служба была недолгой, но открыла будущему полководцу бездну безобразий и несправедливостей, царящих в армии. Александр Васильевич и из этого печального опыта извлек пользу для будущего управления войсками. Но, главное - получил наконец-то трамплин для продвижения в армии.

Когда началась Семилетняя война (1756-1763), Суворов был «выпущен в премьер-майоры» для определения в пехотные полки команды генерал-фельдмаршала А. Б. Бутурлина. В армии это был высокий чин, позволяющий командовать батальоном или эскадронном. Увы, надежда Александра Васильевича попасть на театр военных действий не сбывалась. Русские войска выступили на запад под командой фельдмаршала Апраксина. Бутурлин же, в подчинение коему попал Суворов, был одним из пяти членов Конференции министров, силившейся управлять боевыми действиями из Петербурга. Больше года Суворов латал в армии дыры, формируя маршевые батальоны для отправки в Пруссию, и служил комендантом г. Мемеля (Суворов, 1949: 33), показав начальству отменную распорядительность.

Участие Суворова в Семилетней войне представлено в формулярных списках и, аналитически, в его автобиографии, написанной 22 сентября 1786 г. (Суворов, 1848) и в интересующей нас части дословно повторенной полководцем 28 октября 1790 г. при подаче документа в Герольдмейстерскую контору по случаю пожалования ему графского достоинства и нового герба (Генералиссимус ..., 1947: 17-73). Автобиография 1790 г. и формулярный список с 23-го октября 1742 г. по 6-е мая 1800 г. вошли в классическую публикацию документов Суворова (Суворов, 1949: 1-2).

Командованию легким отрядом в 1761 г. Александр Васильевич уделил в автобиографии в пять раз больше внимания, чем всей предшествующей службе, столько же, сколько важнейшей в его карьере первой турецкой войне, от Туртукая до Козлуджи. Он тщательно суммировал свои наблюдения, зафиксировал и объяснил опыт, полученный в первых самостоятельных боях. Великий полководец сам восстановил для нас картину зарождения его оригинальной военной мысли. В память его, и без того очень цепкую к военным обстоятельствам, врезались мельчайшие детали боев, в ходе которых Александр Васильевич начинал понимать суть войны и победы. Точность воспоминаний полководца подтверждена упоминаниями о его действиях в штабных документах 1761 г. (там же: 57-68).

Александр Васильевич отметил в автобиографии, что участвовал во 
взятии прусского городка Кроссена, надо полагать, волонтером в составе бригады генерал-майора князя Михаила Никитича Волконского, отличившейся затем при Пальциге и Кунерсдорфе. Впоследствии Суворов всегда приветствовал волонтеров и часто держал офицерами при полках сверх штата, находя им применение при себе, т. е. на самых ответственных участках, и щедро представляя к наградам наряду со строевыми. В последнем, величайшем сражении войны, он участвовал в должности дежурного офицера при командующем 1-й дивизией генерал-аншефе В.В.Ферморе.

Александр Васильевич позже писал Потемкину о том, что у него два отца - Суворов и Фермор (Петрушевский, 1884). Неизвестно, чему Суворов научился у Вилима Вилимовича, кроме склонности к наступлению и умению не обижаться на несправедливость начальства. Никто в армии не знал, отчего Фермор, после торжеств и пролившихся на него наград в Санкт-Петербурге, был снят с поста командующего. Прибывший в его штаб Суворов видел смирение, с которым Вилим Вилимович принял отставку, оставшись в армии во главе дивизии.

Более сильное впечатление на Александра Васильевича, ощущавшееся всю его долгую полководческую жизнь, произвел новый командующий: 61-летний генерал-аншеф Петр Семенович Салтыков. Этот мудрый старик (по тем временам), тщательно изучавший тактику Фридриха и боевые свойства русских войск под началом Фермора, разительно отличался от военачальников, с которыми был уже знаком молодой Суворов. 12 августа 1759 г. «старичок седенький, маленький, простенький, в белом ландмилицком кафтане, без всяких дальних украшений и без всех пышностей», который «казался нам, - по словам русского очевидца, - сущей курочкой» (Болотов, 1986: 73), наголову разгромил Фридриха Великого при Кунерсдорфе.

Суворов, находясь при дивизии Фермора как дежурный офицер и наблюдая с наиболее защищенного и высокого западного холма Юденберг перемещения войск, прекрасно понимал, что «курочка» ломает стереотипы военной науки, откровенно подставляясь под излюбленную Фридрихом «косую атаку». Бросая превосходящие силы по касательной на один из флангов противника, окружая его и добивая натиском вдоль фронта, король выиграл уже не одно сражение. Он должен был клюнуть на столь лакомую приманку, как слабый фланг под командой Голицына на низком и пологом холме Мюльберг, в полной мере использовав превосходство прусских войск в выучке, маневренности и управляемости на поле боя. Лишь стойкость русских солдат могла сделать их непобедимыми при выборе хорошей оборонительной позиции с возможностью гибко пользоваться резервами для ответного массирования сил и контратаки. Иная тактика была гибельна для русской армии, пока она не прошла школу Ру- 
мянцева и Суворова. Однако и сам Александр Васильевич впоследствии «подставлял» неприятелю видимо слабую позицию, заставляя врага бросать все его силы в атаку, если сам не мог атаковать. Так было при Гирсово, когда противник в степной местности был мо-бильнее за счет превосходства в кавалерии. Так случилось и при Кинбурне, когда Суворов не имел сил потопить турецкий флот, но заставил турок высадить на узкой косе десант.

В 1760 г. Суворов участвовал в операциях против Пруссии как дежурный офицер при штабе главнокомандующего, которым из-за болезни Салтыкова снова стал Фермор (Суворов, 1949: 3). Даже это далось ему нелегко. После Кунерсдорфа он был назначен обер-кригс-комиссаром, проще говоря, интендантом. Эту службу Александр Васильевич в автобиографии не упомянул, но имеется императорский рескрипт от 25 февраля 1760 г. «о исключении полковника Александра Суворова от исполнения обер-кригскомиссарской должности и определению по прежнему в полк при заграничной армии» (там же: 57). Назначение явно прошло по воле отца, весной 1760 г. направленного в действующую армию главным снабженцем: «генерал-губерпровиантмейстером». Естественно, что честный и распорядительный отец хотел иметь помощника, которому мог безраздельно доверять. Поприще, на котором трудились отец и сын Суворовы, было стратегически важным: без провианта, который они собирали по разоренному войной краю, армия бы погибла. Василий Иванович Суворов не раз заслужил благодарности командования. 25 июля он стал кавалером ордена Александра Невского, а 16 августа 1760 г. был пожалован в сенаторы.

Но его сын, сознавая важность своей миссии, все равно рвался на передний край, мечтая о полях сражений. Лишь после настойчивых просьб младший Суворов был рескриптом императрицы освобожден от ненавистной тыловой должности «и определен по-прежнему в полк при заграничной армии». «В полк» он был назначен условно, т. к. команды вновь не получил, и лишь по знакомству состоял при Ферморе дежурным офицером во время операций 1760-1761 г. в Силезии, Померании и Бранденбурге, возможно, участвовал во взятии Берлина корпусом М. Н. Волконского.

«В 1756 году произведен был обер-провиантмейстером, генералаудитор-лейтенантом, а потом переименован в премьер-майоры, - пишет Суворов в автобиографии, - в котором звании в 1758 году был при формировании третьих батальонов в Лифляндии н Курляндии и имел оных в своей команде семнадцать, которые препроводил в Пруссию, и был комендантом в Мемеле. В том же году пожалован подполковником, был при занятии Кроссена, в Силезии, под командою генерала князь Михаила Никитича Волконского; отправлял должность генерального и дивизионного дежурного при генерале графе Вилиме Вилимовиче Ферморе, 
был на франкфуртской баталии (при Куренсдорфе) и в разных партиях». Сохранилось несколько приказов Фермора и Бутурлина, переданных из «генерального дежурства армии» «дежурным подполковником Суворовым» (там же: 57-63).

В кампании 1761 г. русское воинство под командой А. Б. Бутурлина совместно с австрийцами окружило, а затем благополучно упустило армию Фридриха. Лишь корпус Румянцева поддержал славу русского оружия, овладев к концу года сильной крепостью Кольберг. Суворов успел поучаствовать и здесь, неведомо какими путями попав в офицеры при новом командующем легким кавалерийским корпусом генерал-поручике Густаве Густавовиче Берге.

«В 1761-м состоял в легком корпусе при генерале Берге, - вспоминал Суворов в автобиографии, - и был под Бригом, при сражении бреславльском с генералом Кноблохом и разных шармицелях, на сражении близ Штригау, при Грос- и Клейн-Вандриссе, где предводил крылом и две тысячи российского войска. Четыре силезских мили противоборствовали армии под королем прусским целой день, а к ночи (русские) сбили их форпосты и одержали место своими. На другой день сими войсками чинено было сильное нападение на левое прусское крыло, против монастыря Вальдштатт; потом был в разных неважных акциях и шармицелях» (там же: 34).

Именно Бергу довелось первым оценить боевые качества 30-летнего «молодого» офицера Суворова. 44-летний прибалтийский немец, участвовавший в своей первой войне и выдвинувшийся отважной атакой во главе драгунского полка под Кунерсдорфом, решился дать Александру Васильевичу команду над сводным отрядом легкой конницы - гусар и казаков с которым Суворов совершил первые подвиги.

Командованию легким отрядом в 1761 г. Александр Васильевич уделил в автобиографии в пять раз больше внимания, чем всей предшествующей службе, столько же, сколько важнейшей в его карьере первой турецкой войне, от Туртукая до Козлуджи. Он тщательно суммировал свои наблюдения, зафиксировал и объяснил опыт, полученный в первых самостоятельных боях. Подчеркну еще раз: великий полководец сам восстановил для нас в 1786 г. и в 1790 г. дословно повторил картину зарождения его оригинальной военной мысли. В память его, и без того очень цепкую к военным обстоятельствам, врезались мельчайшие детали боев, в ходе которых Александр Васильевич начинал понимать суть войны и победы. Точность воспоминаний полководца подтверждена упоминаниями о его действиях в штабных документах 1761 г. (там же: 57-68).

Основы будущей «Науки побеждать» были в это время заложены в сознании Суворова. Смысл их развернутого изложения в автобиографии понятен. С точки зрения карьеры Александра Васильевича его действия 
в чине подполковника против пруссаков в 1761 г. не имели особого значения для генерал-аншефа, мечтающего о чине фельдмаршала в 1786 и 1790 гг. Но для истории становления его военной концепции они были принципиальны. В документальном смысле это была лакуна. Дальнейшие наблюдения и размышления полководца будут с нарастающей подробностью освещены во многих, прежде всего, принадлежащих ему письменных источниках. Но относительно его внутреннего развития в Семилетнюю войну «неложных свидетелей» не было: журналы действующей армии фиксировали лишь простые факты его назначений и поручений. Для полководца, который не упускал в картине военных событий ни малейшей детали, представляя в письменных текстах самое главное, оставить такое «белое пятно» было немыслимо. За заполнение этой единственной лакуны историки обязаны принести Александру Васильевичу огромную искреннюю благодарность. Итак, последуем за полководцем в его первых самостоятельных боевых успехах, которые он оценил для себя чрезвычайно высоко.

Корпус Берга успешно наступал в Силезии. Суворов участвовал во многих битвах (под Бригом, Бреслау, Штригау, при Гросс- и КлейнВандриссе), а в сражении под Вальштадтом два дня возглавлял наступление 2-тысячного отряда, на четыре мили отбросившего королевские войска. Это был первый успех, который Александр Васильевич запомнил как личный и счел необходимым описать. Но действительно подробные воспоминания начинаются далее, с командования совсем крошечным отрядом, действия которого стали первыми шагами в становлении искусства будущего великого полководца.

В боях под крепостью Швейдниц Александр Васильевич с отрядом казаков трижды ходил в атаку на ключевую высоту, взял ее и несколько часов удерживал против многократно превосходящего неприятеля. Донские казаки, имевшие на вооружении пики, сабли и карабины, были иррегулярным войском. Они смело атаковали рассыпного противника на конях и сами сражались пешими в рассыпном строю. Метко стреляя, используя для укрытия от ответного огня рельеф местности, они являлись необычным в европейских армиях и действенным родом иррегулярных войск.

Отбив атаки противника, Суворов получил подкрепление из двух казачьих полков и сам атаковал прусскую кавалерию, маневрировавшую у подножия высоты. Четыре полка прусских гусар и драгун были опрокинуты, разбиты и загнаны в королевский лагерь. Господствующая высота осталась в руках казаков. «Отсюда, - вспоминал Александр Васильевич в автобиографии, - весь прусский лагерь был вскрыт, и тут утверждена легкого корпуса главная квартира».

Установив соединение форпостами с бездействующими русской и 
ав-стрийской армиями, Берг с занятой Суворовым высоты атаковал то и дело выходившую из лагеря Фридриха кавалерию. В одной из таких стычек, в которых участвовал Суворов, русские кавалеристы гнали четыре прусских полка до самого королевского шатра. «Сверх разных примечательных (дел), - с удовольствием вспоминал много лет спустя Александр Васильевич, - единожды под королевскими шатрами разбиты были драгунские полки, при моем нахождении, Финкенштейнов и Голштейн, (и) гусарские - Лоссов и Малаховский, с великим для них уроном».

В отличие от почти всей европейской кавалерии того времени, ведомые Суворовым гусары с саблями и казаки с пиками атаковали на полном галопе. Даже вымуштрованные прусские кавалеристы, приученные своими командирами не только стрелять с шага, но и атаковать холодным оружием на галопе, были поражены молниеносными атаками и сокрушительным натиском суворовских конников. Пруссаки встретили противника, который не только бился с ними на равных, но и побеждал их в открытом кавалерийском бою.

Для многих командиров конная сшибка на «белом» оружии была хорошо забытым прошлым. Кавалерия как элитный род войск вооружалась до зубов. Даже легкие конники-гусары имели, помимо сабли, по два седельных пистолета, дополненные в тяжелой кавалерии кирасир и драгун еще и висевшим на перевязи карабином. Западные и русские кирасиры, конно-гренадеры и карабинеры разрывались между задачей стрелять залпами, как линейная пехота, и атаковать холодным оружием. То и другое требовало плотного, ровного строя, но стрельбу можно было вести, только стоя на месте или наступая шагом, а эффективная атака холодным оружием требовала, как минимум, скакать галопом, а лучше всего - с максимальной скоростью, в карьер. Удобная для поддержания строя рысь не годилась в схватке ни на что. Стремительная атака строем обычно приносила победу, оглушительная пальба была неэффективной, но военная мысль упорно цеплялась за изобилие стволов, которыми были увешаны тяжелые и даже легкие кавалеристы.

Превращение кавалериста в передвижной арсенал сложилось исторически и имело социальные корни. Развитие огнестрельного оружия побуждало феодалов-кавалеров к усилению с его помощью преимуществ излюбленного ими конного строя. B XVI в. появился даже особый род кавалерии - драгуны, которые должны были стрелять в пешем строю. B XVII в. шведский король Густав-Адольф одержал ряд побед, осознав, что использовать всадников вместо пехоты нелепо, как и терять в атаке время на стрельбу. И кавалерия Карла XII побеждала всех атакой на галопе, пока не столкнулась с еще более стремительной кавалерией князя Меншикова под Полтавой. В середине XVIII в. быстрыми маневрами и сокрушитель- 
ными атаками в плотном строю прославились кирасирские и драгунские полки Фридриха Великого. Его всадники, выдвигаясь «быстрой рысью», неслись на противника в «сомкнутом строю» «полным галопом» «с палашом в руке, - и ни один командир под угрозой позорного разжалования не должен позволять своей части стрелять», - требовал прусский король (Энгельс, 1956: 216).

Русский устав тяжелой кавалерии, принятый перед Семилетней войной, в этом вопросе мало уступал прусскому. Устав требовал, подъехав к противнику «малой рысью» (вместо прусской быстрой) на 100 или даже 300 сажен и выровняв ряды, атаковать без стрельбы, «добрым галопом» (Экзерциция, 1755: ч. 1, параграф 51-52), «во всю скачь» (п. 77), и рубить противника вперед, привстав на стременах, через голову лошади (п. 129). Только при разбитии фронта неприятеля, когда всадники по команде бросались в преследование поодиночке, разрешалось стрелять из пистолетов. Увы, этот правильный кавалерийский удар был, как и у пруссаков, кинжальным. Большую часть времени кавалерия тратила на маневры, перестроения и выравнивания с бесконечными командами «Стой, равняйся!» И - на стрельбу.

Полк русской кавалерии в момент, когда на поле боя появился Суворов, был грузной неповоротливой силой, которую противник мог атаковать с тыла и с флангов, для чего в Уставе 1755 г. предлагались разные способы отражения атак, особые команды, рисовались сложные схемы. Кавалерия, как пехота, даже строилась в каре - квадрат со стороной в две шеренги (п. 107-117). Строй этот был сочинен в XVII в. как оборонительный и считался таковым до Фокшан и Рымника, когда Суворов, запретив в пехотном каре команду «стой», превратит группу батальонных каре, наступающих непрерывно, паля с фасов из пушек, в передвижную крепость, рвущую позиции противника на глубину в 20 верст. Для кавалерии этот негибкий строй был губителен, и Суворовым впоследствии начисто отвергнут. Абсолютно им было запрещено говорить о «ретирадных и отступных боях», да еще с пальбой, подробно описанных Уставом (Гл. 9). Вторая часть Устава 1755 г. была полностью посвящена действиям кавалерии в пешем строю; третья - пальбе, включая «отступную пальбу всем фронтом», залпами (Ч. 3. Гл. 4, 8) - делам, как убедился Суворов, бессмысленным и ведущим к поражению.

Господствующая в европейских армиях линейная тактика, которую усовершенствовал маневром и решительной атакой Фридрих Великий, подразумевала развитие старой идеи: максимальное повышение огневой мощи выстроенной в четкие порядки и медленно, чтобы не сбивать прицел, надвигающейся на противника или ретирующейся конницы. Вера в силу залпового огня была столь велика, что его максимальное ис- 
пользование составляло основную по объему часть военных инструкций. Лишь немногие, в их числе наблюдательный Суворов, усомнились в его губительности. Действительно, залп из весьма неточных мушкетов и еще менее способных попасть в цель пистолетов мог нанести сильный урон только большой по площади и малоподвижной мишени. Можно сказать, что он был смертелен, только если обе стороны «играли по правилам», сметая залпами линию противника и подставляя свою линию под столь же губительные залпы.

На деле огневой залп из пистолетов, мушкетов и даже пушек по стремительно движущейся цели был, как обнаружил Суворов, крайне неэффективен. Превосходная кавалерия Зейдлица была расстреляна на его глазах при Кунерсдорфе лишь потому, что атаковала под прицельным огнем русских пушек медленно и крайне скученно, по узким и топким проходам между озерами. При этом ускоренное, относительно практики и военных руководств, движение вперед, на врага, способное принести победу, оказалось менее опасным, чем бессмысленные в глазах Суворова перестроения и «шатания» вдоль фронта, не говоря о губительной и впоследствии строго запрещенной Александром Васильевичем «ретираде»отступлении.

Вы спросите, как можно говорить о «смысле» в человекоубийстве?! Суворов тоже всю жизнь задавал себе этот вопрос, и отвечал на него делом: стремительная и победоносная атака, ставшая в его глазах залогом победы, сберегала огромное число жизней. Причем не только своих бойцов, но и солдат противника. Ошеломленного и разгромленного врага следовало щадить и брать в плен. Не случайно Суворов с этих дней на германской земле и на всю жизнь запомнил (рассказав в автобиографии), сколь малые потери он нес сам, и сколько пруссаков спас, забрав в плен.

Русские и австрийские войска под командой Бутурлина и Лаудона бесславно отступили от Швейдница, предоставив Фридриху Великому полную свободу. Пока русская и австрийская армия совершали сложные и бесполезные маневры, корпус Берга был брошен наперерез 12-тысячному отряду генерала Платена, пытавшегося деблокировать обложенный Румянцевым Кольберг. Генерал был достойнейшим противником. Получив приказ помешать русским операциям в Померании, он стремительным рейдом разгромил русские магазины в Польше, прорвался в Познань и через Бреслау устремился Румянцеву в тыл. Фридрих Великий надеялся, что остановить или задержать его неповоротливые русские войска не смогут.

Берг мог выполнить приказ, лишь противопоставив прусской инициативе офицеров, которые не станут ждать дополнительных приказов и инструкций. Выступая в поход, он специально просил командование оставить Суворова в его корпусе. Приказ по заграничной армии свиде- 
тельствует, что Густав Густавович высоко оценил военный талант Александра Васильевича: «Так как генерал-майор Берг выхваляет особливую способность подполковника Казанского полка Суворова, то явиться ему в команду означенного корпуса» (Суворов, 1949: 57). Подполковник полетел в штаб Берга, как на крыльях. Много позже, будучи генерал-аншефом и одержав великие победы под Кинбурном, при Фокшанах и Рымнике, Александр Васильевич с особым удовольствием вспомнил свои действия во главе небольших кавалерийских отрядов, которые ему доверял Берг. Еще бы: впервые начинающий полководец мог в полной мере проявить инициативу, не будучи связанным вышестоящим начальством.

Берг сделал Суворова своей правой рукой, позволяя ему брать под команду отряды, находившиеся ближе всех к противнику. Задачей было постоянно связывать противника боем, сковать его маневр и нанести максимальный урон. Разгромить корпус Платена Суворов с имеющимися силами не мог, но сделать его бесполезным в стратегических планах Фридриха Великого был способен.

Русские нагнали пруссаков ночью, при местечке Костяны в Польше. Суворов вышел на лагерь Платена с тыла, сквозь густой лес, и, вопреки всем уставам и традициям, повел кавалерию в атаку по неизвестной пересеченной местности в темноте. Понеся «знатный урон», противник спешно снялся с лагеря и постарался оторваться от русских. Через два дня Суворов нагнал его и нанес новый удар. Чтобы оценить эти действия Александра Васильевича, полезно вспомнить, что ночная атака кавалерии, как и ее динамичные действия во фланг и тыл противника, которые Суворов будет развивать в польских и турецких кампаниях, станут уставными только при Павле I (Устав коннаго полка, 1797; Правила о службе кавалерийской ..., 1830; Воинский Устав о полевой кавалерийской службе ..., 1830; Воинский устав о полевой гусарской службе, 1797). Военный гений Суворова проявился, прежде всего, в целесообразности его действий, невзирая на нормы, а затем в способности понять истинные причины успеха и возвести их в правила.

12 сентября 1761 г. Бергу стало известно, что корпус Платена приближается к Ландсбергу, собираясь форсировать Варту по ведущему в город мосту. Перехватить противника основными силами Берг не успевал. Помешать переправе мог только Донской казачий полк С. Т. Туроверова, которому Берг приказал «мост через Варту разорить и неприятелю в переходе препятствовать» (там же: 63). Важное поручение взялся выполнить Суворов. «Взял я с собою слабый, во ста конях, Туроверова казачий полк», вспоминал Александр Васильевич о том, как рождалась его «Наука побеждать». Ночью сотня донцов Туроверова с Суворовым во главе переплыла на конях речку Нетце и проскакала по противоположному берегу Варты 
до Ландсберга. Внезапным броском через ров казаки захватили городские ворота. Предусмотрительно посланные сюда Платеном две прусские команды были взяты в плен. Текст автобиографии Суворова подтверждается Журналом боевых действий армии генерала А.Б. Бутурлина за 1761 г. О взятии Ландсберга 12 сентября там уточнено, что «по вступлении в город взяты в полон гусарский ротмистр один, подпоручик один, вахмистр один, трубач один и гусар 24 человека» (Генералиссимус ..., 1947: 110).

Суворов сжег «Ландсбергский большой мост» как раз к моменту, когда на противоположном берегу показались основные силы Платена. К сожалению Александра Васильевича, пруссаки все равно сумели переправиться на понтонах, «за нескорым прибытием нашего легкого корпуса». Не в силах ускорить свой марш, Берг дал Суворову все свои мобильные силы: семь казачьих (неполного состава) полков под командой полковника Попова и три гусарских полка под началом полковника Зорича. C этими силами Александр Васильевич 15 сентября настиг пруссаков при выходе из Фридебергского леса, уже на самой границе Померании.

Крепкий профессионал Платен был вполне готов к отпору. Его основные силы совершали марш по высотам, с которых вся прусская артиллерия открыла по русским огонь. Но казаки и гусары атаковали стремительнее, чем меняли прицел пушкари. Проскочив «под огнем», русские порубили фланговые эскадроны Платена, положив на месте сотню драгун и взяв 71 пленного, в том числе офицера штаба корпуса (там же: 110-111). Суворов навсегда запомнил, что - несмотря на ужасающую канонаду «всей» (это им подчеркнуто) прусской артиллерии и знаменитую выучку прусских драгун - стремительно атаковавшие силы почти не понесли потерь: пять раненых было у казаков и несколько среди гусар.

«Останавливал я Платена на марше сколько возможно», - констатировал Суворов, до тех пор, пока прусский корпус не вошел в зону ответственности командира 3-й дивизии генерала Василия Михайловича Долгорукова. Корпус Берга был остановлен под Старгардом на кратковременный отдых. Платен все же сумел прорваться под Кольберг, где соединился с войсками принца Вюртембергского. Однако Долгоруков прибыл к Кольбергу раньше, усилив осаждающие крепость войска Румянцева, а кавалерия Берга, выступив на Регенвальде, парализовала коммуникации противника.

В начале октября Берг атаковал и пленил отряд майора Подчарли в деревне Вейсентин. Суворов участвовал в атаке во главе отряда легкой кавалерии, а при отходе прикрывал тыл русских войск. Отважный подполковник де Корбьер (будущий фельдмаршал) преследовал Берга во главе пяти прусских эскадронов с конной артиллерией. Имея меньше 
ста донских казаков и «желтых» сербских гусар ${ }^{1}$, Суворов стремительной контратакой отбросил противника и взял много пленных. Сербских гусар высокие начальники не воспринимали всерьез, но Александр Васильевич их хвалил. Сербы под командой полковника Хорвата начали переселяться в Россию, с обязательством сформировать гусарский полк, еще в 1751 г., и получили земли в бассейне Южного Буга. За ними сюда потянулись и другие балканские христиане. За новую родину они бились отважно.

Суворову же вскоре повезло, наконец, получить под команду собственный регимент. Командир Тверского драгунского полка заболел, а на его заместителя, «по недавнему вступлению из итальянцев в нашу службу», по мнению генерал-майора Берга, было «положиться невозможно». По просьбе Берга командование полком было возложено на Суворова, чья «способность ему, генерал-майору, весьма известна». Ордер о назначении подполковника Суворова командиром полка был записан в журнал боевых действий 17 ноября (Суворов, 1990: 61).

20 ноября под Наугардом Александр Васильевич в составе одной колонны корпуса Берга атаковал деревню, занятую батальоном прусских гренадеров (помимо мушкета, вооруженных ручными гранатами) и двумя батальонами знаменитого впоследствии полководца принца Фердинанда, с приданым им «слабым» (по оценке Суворова) полком драгун из Голштейна. Подполковник, что характерно, при скоротечной схватке успел выяснить и навсегда запомнил реальные силы противника: голштейнский полк насчитывал 6 эскадронов вместо штатных 10-ти, т. е. (штатно) 930 человек вместо 1550-ти. Штат во время войны полон не был, так что конных голштинцев могло насчитываться столько же, сколько русских драгун и гусар, или меньше. Суворов лично повел Тверской полк в атаку с правого фланга, а полковник Зорич с гусарами Венгерского и Хорватского полков - с левого; казаки бригадира Краснощекова маневрировали по фронту.

Тверские драгуны имели, кроме палашей, карабины, и, теоретически, были обучены сражаться в конном и пешем строю. На деле они в том и другом уступали по выучке пруссакам, и уж точно не могли на равных драться с отборными гренадерами короля Фридриха. Но местность была пересеченная, непригодная для наступления ровным строем, удобным для вымуштрованных пруссаков. Суворов бросил полк в стремительную атаку холодным оружием: «Тверской полк, около двухсот пятидесяти человек, врубился в пехоту на неровном месте и сбил драгун. Урон прусской в убитых и пленных был велик, и взята часть артиллерии».

Вновь быстрота и смелость атаки позволили одолеть превосходя-

${ }^{1}$ Сербы под командой полковника Хорвата начали переселяться в Россию, с обязательством сформировать гусарский полк, еще в 1751 г., и получили земли в бассейне Южного Буга. За ними сюда потянулись и другие балканские христиане. 
щие силы противника. Прусский батальон полного состава насчитывал 810 солдат и офицеров. Суворову противостояло если не 2,5 , то с учетом обычного на войне некомплекта, не менее 1,5 пехотинцев и шесть эскадронов драгун, плюс артиллеристы: около 3 обороняющихся пруссаков на одного наступающего русского, даже если гусар у Зорича было вдвое больше, чем у Суворова драгун! «Подо мною расстреляна лошадь и другая ранена», - так Александр Васильевич обозначил ярость схватки. Пруссаки, согласно Журналу боевых действий корпуса генерала П. А. Румянцева, потеряли, «кроме побитых», 80 человек пленными и одну пушку; «с нашей же стороны урон весьма мал» (Генералиссимус ..., 1947: 111-112). Русские, вопреки европейской военной науке и практике, победили! Значит, что-то неладно было с военной наукой, и был какой-то неведомый миру источник победы, позволявший Суворову бить врага при неравном соотношении сил.

Русское и прусское командование о начавшейся революции в военном деле не ведали, и продолжали воевать по старинке, дополняя линейную тактику кордонной стратегией. Обе стороны боролись за пути сообщения между Кольбергом и Штеттином, маневрируя вокруг стоявшей на этой операционной линии крепости Трептов. С прусской стороны действовал хорошо знакомый Суворову корпус Платена. С русской - корпус Берга, соединившийся с отрядом тяжелой кавалерии князя Михаила Никитича Волконского. Князь, заслуживший чин генерал-поручика смелыми атаками при Пальциге и Кунерсдорфе и уже проведший полки своих конных гренадер и кирасир парадом по Берлину, действовал в наступательном духе.

Русский и прусский авангарды сошлись у Ренегвальда. Волконский немедля повел конных гренадер в атаку «на палашах» (тяжелая кавалерия была вооружена длинными и тяжелыми прямыми палашами вместо сабель). Прусская пехота авангарда де Корбиера была смята. Тем временем «гусары сразились с гусарами». «Весь сильный авангард под полковником Курбьером взят был в плен, - вспоминал Суворов, - и его артиллерия досталась в наши руки». В рапорте императрице Елизавете Петровне Румянцев отметил, что корпус Берга, не потеряв ни единого человека, «до тысячи рядовых и с предводителем подполковником Корбиером в плен взял».

Особенно подробно Александр Васильевич вспоминал на первый взгляд беспорядочную, но с его точки зрения весьма поучительную баталию у Ренегвальда, когда «осенью, в мокрое время», корпус Берга разделился. «Регулярная конница его просила идти окружной, гладкой дорогой. Он (Берг. - A. Б.) взял при себе эскадрона три гусар и два полка казаков и закрывал корпус поодаль справа». Суворов был в отряде, максимально близком к неприятелю. «Выходя из лесу, - вспоминал он, - вдруг увидели мы на нескольких шагах весь прусской корпус, стоящий в его линиях». 
Силы были неравны даже для Суворова. Решение надо было принимать мгновенно.

Пока противник не опомнился, русская кавалерия поскакала вдоль его фронта влево. Этот выбор оказался правильным. Посланный в разведку офицер донес, «что впереди, в большой версте, незанятая болотная переправа мелка. Мы устремились на нее. Погнались за нами вначале прусские драгуны на палашах, за ними - гусары. Достигнув переправы, приятель и неприятель, смешавшись, погрузли в ней почти по луку (седла. $-A$. Б.). Нашим надлежало прежде насухо выйти. За ними вмиг - несколько прусских эскадронов, которые вмиг построились. Генерал (Берг. - А. Б.) - приказал их сломить. Ближний эскадрон был слабый желтый Сватченков; я его пустил. Он опроверг все прусские эскадроны обратно в болото.Через него, между тем, нашли они слева от нас суше переправу. Первый их полк перешел драгунский Финкенштейнов, весьма комплектный (около 1500 всадников. - A. Б.). При ближних тут высотах было отверстие на эскадрон, против которого один (полк. - A. Б.) Финкенштейнов встал».

Атаковать противника, пока тот сам не приготовился к атаке, мог сквозь узкое дефиле между холмами лишь один эскадрон. Но что он мог сделать против комплектного полка в 10 эскадронов, даже если через переправу из них (как пишет дальше Суворов) перешла лишь половина? «Невозможно было время тратить; я велел ударить стремглав на полк одному нашему сербскому эскадрону. Его капитан Жадр бросился в отверстие (между холмов. - A. Б.) на саблях. Финкенштейновы дали залп из карабинов. Ни один человек из наших не упал, но Финкенштейновы пять эскадронов в мгновенье были опрокинуты, вырублены, потоптаны и перебежали через переправу назад».

Не встретив храбрых сербов контратакой и пытаясь, по уставу, дружно стрелять, прусские кавалеристы проиграли схватку, а вместе с нею весь бой. С нашей стороны «сербский эскадрон был подкрепляем одним венгерским, который в деле не был. Финкенштейновы же были подкрепляемы, кроме конницы, батальонами десятью пехоты. Вся эта пехота прекрасное зрелище с противной черты - на полувыстреле давала в нас ружейные залпы», - с удовольствием вспоминал Александр Васильевич.

Несмотря на идеальное расстояние для залпового огня лучшей в Европе линейной пехоты, гарцующие на нашем берегу заболоченной речушки сербы и венгры оставались неуязвимыми. И многократно более сильный по численности противник, потеряв лишь мгновение при принятии решения об атаке в карьер, начисто проиграл схватку!

«Мы почти ничего не потеряли, - констатировал Суворов, - от них же, сверх убитых, получили знатное число пленников». А ведь пруссаками командовали не новички: «при сих действиях находились их лучшие пар- 
тизаны, и Финкенштейновым полком командовал подполковник и кавалер Рейценштейн - весьма храбрый и отличный офицер. Потом оставили они нас в покое».

Торжество идеи, что кто быстрей и энергичней атакует, тот побеждает, было полным. Однако годится ли эта мысль для пехоты? Суворов проверил это на себе в самых жестких условиях, при первой же возможности возглавив атаку пехоты на укрепленный по средневековому образцу городок Гольнау (Голнов). Штурм вышел кровавым, но успешным, а потери оказались не столь велики, как при «правильной» осаде. Но предоставим слово самому полководцу, вспоминавшему в автобиографии о событиях осени 1761 г.: «В ночи прусский корпус стал за Голновым, оставив в городе гарнизон. Генерал граф Петр Иванович Панин прибыл к нам с некоторой пехотой. Я с одним гренадерским батальоном атаковал ворота, и, после сильного сопротивления, вломились мы в калитку, гнали прусский отряд штыками через весь город за противные ворота и мост, до их лагеря, где побито и взято много в плен. Я поврежден был контузией, в ногу и грудь картечинами; одна лошадь убита подо мной». Оказалось, что и в пехоте быстрота и натиск решают исход боя. Русские победили с минимальными потерями. Наибольшей опасности при штурме подвергались офицеры, на которых осажденные сосредотачивали огонь.

Как видим, на войну против Пруссии зрелого возраста офицер пришел еще «чистым листом». Он искренне представлял своим «учителем» и «отцом» генерала Фермора, сражавшегося по старому уставу, и пришел в восторг от фельдмаршала Салтыкова, разбившего Фридриха Великого в позиционном сражении при Куренсдорфе лишь благодаря верной оценке слабых и сильных сторон своих сил и знанию свойств противника. Лишь затем, возглавив отдельный кавалерийский отряд в корпусе генерала Берга, Суворов начал делать открытия. Оказалось, что при существующих вооружениях и тактике смелая атака в не упущенное мгновение - не только самый целесообразный, но и наименее опасный способ разбить противника, несмотря на его серьезное превосходство. Пехота и кавалерия, начав, как было принято, стрелять залпами, не выдерживала стремительной атаки даже небольших сил. И на артиллерию оказалось полезным скакать карьером, под выстрелы, идущие выше голов. И даже сильную крепость можно было взять штыковым ударом пехоты.

Эти выводы, полученные из практики, Суворов запомнил на всю жизнь, подробно изложив в автобиографии. Но в 1760-х доводы обычного полковника (произведен в 1762 г. по представлению Румянцева) никого не интересовали и в работе над новыми уставами учтены не были. Из этого он тоже сделал вывод - став генералом, требовал от офицеров докладывать не только факты, но мыслии предложения, не боясь ошибиться и 
помогая командующему принять верное решение. Мысль, что младшему командиру на месте событий виднее, что делать, оформленная в приказах намного позже, пришла Александру Васильевичу именно на Прусской войне и после нее, когда он сам пытался достучаться до начальства, полагавшего, что «виднее сверху».

\section{СПИСОК ЛИТЕРАТУРЫ}

Автократова, М. И. (1956) А. В. Суворов - обер-провиантмейстер (1756г.) // Исторический архив. № 2. С. 213.

Апушкин, В. А. (1899) Суворов - генерал-аудитор-лейтенант // Русский инвалид. 2 декабря. № 263. С. 2-3.

Богданов, А. П. (2014) Суворов. М. : Вече. 448 с.

Болотов, А. Т. (1986) Жизнь и приключения Андрея Болотова, описанные самим им для своих потомков : в 3 т. М. (указывается номер письма).

Воинский устав о полевой гусарской службе (1797). М.

Воинский Устав о полевой кавалерийской службе от 29.11 .1796 (1830) // Полное собрание законов Российской империи. Собрание первое. Т. 24. СПб. № 17.590 .

Генералиссимус Суворов (1947) : сб. документов и материалов. Л. : ОГИЗ. № 4.

Петрушевский, А. Ф. (1884) Генералиссимус князь Суворов : в 3 т. СПб.: Типография М. М. Стасюлевича. Т. 1.

Правила о службе кавалерийской от 29.11.1796 (1830) // Полное собрание законов Российской империи. Собрание первое. Т. 24. СПб. № 17.589.

Суворов, А. В. (1848) Автобиография // Чтения в императорском обществе истории и древностей российских при Московском университете. M. № 9. С. 534-552.

Суворов, А. В. (1949) Документы : в 4 т. М. : Воениздат. Т. І. (указывается номер документа).

Суворов, А. В. (1987) Письма / изд. В. С. Лопатин. М. : Наука. 808 с. (указывается номер письма).

Суворов, А. В. (1990) Походы и сражения в письмах и записках. М. : Воениздат. 528 с.

Устав коннаго полка. О службе кавалерийской (1797). СПб.

Экзерциция и учреждение строев и всяких церемониалов регулярной кавалерии 1755 году (1755). СП. : Типография Академии наук. 159 с.

Энгельс, Ф. (1956) Кавалерия // Энгельс Ф. Избранные военные произведения. М. : Воениздат. 844 с. 
Богданов Андрей Петрович - доктор исторических наук, ведущий научный сотрудник Института российской истории Российской Академии наук. Адрес: 117036, Россия, Москва, ул. Дмитрия Ульянова, д. 19, каб. 40. Эл. адрес: bogdanovap@mail.ru

Bogdanov Andrey Petrovich, Doctor of History, Leading researcher, Insti-tute of Russian history, Russian Academy of Sciences. Postal address: Office 40, 19 Dmitry Ulyanov St., 117036 Moscow, Russian Federation. E-mail: bogdanovap@mail.ru 